\title{
KOMBINASI MEDIA TANAM DAN PEMBERIAN BERBAGAI DOSIS PUPUK GROW QUICK LB TERHADAP PERTUMBUHAN ANGGREK DENDROBIUM (Dendrobium sp.) PASCA AKLIMATISASI
}

\author{
Nofripa Herlina, Novia Gesriantuti, Anis Restiawati \\ Program Studi Biologi, Fakultas MIPA dan Kesehatan \\ Universitas Muhammadiyah Riau \\ Jl. Tuanku Tambusai Ujung, Pekanbaru 28291, Riau \\ e-mail: nofripaherlina@umri.ac.id
}

\section{ABSTRACT}

Dendrobium orchid is one of the very popular ornamental plant because of the flower is beautiful and has a high economic value. An effort to prevent the orchid from extinetion is by means of in vitro propagation. The study aims to look at the effect of various doses of fertilizers Grow Quick LB and types of growing media and their interaction on the growth of Dendrobium sp. post acclimatization. The completely randomized design was used with two factors. The firs factor was type medium (charcoal+fern, charcoal+cocopeat), the second factor was type of Grow Quick LB fertilizer $(0 \mathrm{ml} / \mathrm{L}, 1 \mathrm{ml} / \mathrm{L}, 2 \mathrm{ml} / \mathrm{L}, 3 \mathrm{ml} / \mathrm{L})$. Parameters observed were, plantlet height, leaf length, leaf width, and number of leaves. The results showed that the dosing of Grow Quick LB fertilizer $1 \mathrm{ml} / \mathrm{L}$ showed the highest values for the parameters width of leaves and number of leaves, whereas a dose of $2 \mathrm{ml} / \mathrm{L}$ showed the highest values for the parameters plantlet height, leaf length. A combination of types of growing media charcoal+cocopeat showed a better effect than the media charcoal+fern on all parameters. The interaction of medium type and Grow Quick LB fertilizer significantly different with plantlet height and leaf length and not significantly different with parameters leaf width, and number of leaves.

Keywords: acclimatization, Dendrobium sp., Grow Quick LB

\section{PENDAHULUAN}

Anggrek (Orchidaceae) merupakan salah satu tanaman hias yang banyak diminati masyarakat luas. Tanaman ini sangat indah dan mempunyai nilai ekonomis yang tinggi. Tanaman anggrek saat ini yang paling popular diperjual belikan adalah Dendrobium. Keistimewaan anggrek ini sebagai bunga potong adalah mudah ditanam, berbunga terus-menerus, warna bunga bervariasi, berbatang lentur sehingga mudah dirangkai dan kesegaran bunga tahan lama (Surtinah dan Mutryarny, 2013).

Indonesia menjadikan anggrek sebagai bunga nasional. Pada tahun 1999, pemerintah Indonesia mengeluarkan PP Nomor 7 yang mengatur tentang perlindungan anggrek. Dendrobium merupakan salah satu jenis anggrek yang masuk dalam daftar Appendix I CITES (Convention on International Trade in Endangered Species) yaitu perdagangan internasional yang bersifat komersial dan seluruhnya dilarang kecuali dari hasil penangkaran (Indarto, 2015). Oleh karena itu para pencinta anggrek atau pedagang anggrek tidak dibenarkan memperdagangkan anggrek yang diambil dari hutan tetapi menjual hasil penangkaran agar anggrek yang sulit tumbuh atau langka tidak punah.

Upaya pencegahan anggrek dari kelangkaan atau kepunahan adalah dengan cara perbanyakan. Perbanyakan tanaman anggrek pada umumnya dilakukan melalui dua cara yaitu metode kultur in vitro dan konvensional (Purnami, et al., 2014). Budidaya anggrek secara konvensional yaitu dengan cara pemisahan tunas pada tanaman dewasa karena dianggap lebih mudah dan tidak memerlukan banyak perawatan, namun cara ini tidak bisa diperbanyak dalam jumlah besar sehingga perlu menggunakan metode in vitro (kultur jaringan).

Kultur jaringan secara luas dapat didefinisikan sebagai usaha mengisolasi, menumbuhkan, memperbanyak, dan meregenerasikan protoplas (bagian hidup dari sel), sel utuh atau bagian tanaman dalam suatu lingkungan aseptik yang terkendali (Gunawan, 2001). Metode kultur in vitro mempunyai kelebihan akan kemampuannya memproduksi anakan secara massal (dalam jumlah banyak) hingga ribuan dengan sifat dan bentuk yang sama persis dengan induknya 
(Indarto, 2015).

Bibit anggrek hasil in vitro umumnya masih bersifat heterotrof atau belum bisa menyediakan makanan sendiri. Periode bibit merupakan tahap saat tanaman Dendrobium baru dikeluarkan dari botol kultur. Tujuan dari periode bibit yaitu untuk mendapatkan pertumbuhan tanaman, seperti jumlah daun, lebar daun, dan tinggi tanaman. Menurut Purnami, et al. (2014) bibit anggrek hasil kultur in vitro masih rentan terhadap perubahan kondisi lingkungan, hama serta penyakit, sehingga dibutuhkan tahap aklimatisasi atau proses adaptasi tanaman dari kondisi in vitro ke kondisi ex vitro. Setelah proses aklimatisasi, untuk mengurangi shock pada tanaman setelah pemindahan media dibutuhkan vitamin B1.

Vitamin B1 terkandung dalam salah satu pupuk yaitu Grow Quick LB (Leaf Booster). Grow Quick LB merupakan pupuk cair pemacu tumbuh tanaman pada semua jenis tanaman yang penggunaannya dengan cara disemprotkan ke daun. Penelitian tentang pemakaian pupuk Grow Quick LB telah pernah dilakukan antara lain oleh Julhendri, et al. (2013) yaitu aklimatisasi tanaman Anthurium (Anthurium sp.) dengan berbagai media tumbuh dan pupuk daun Grow Quick dan didapatkan perlakuan terbaik pada perlakuan Grow Quick 7,5 ml/L. Sedangkan pada tanaman Anggrek telah dilakukan penelitian frekuensi pemberian Grow Quick LB terhadap pertumbuhan bibit anggrek Dendrobium pada stadia komunitas pot dengan dosis pemberian Grow Quick LB 1 sendok teh/4 L atau $1 \mathrm{~g} / \mathrm{L}$ dan penelitian dilakukan selama 1,5 bulan serta didapatkan perlakuan terbaik pemberian pupuk Grow Quick LB 3 hari sekali (Surtinah dan Murtryarny, 2013). Penelitian yang telah dilakukan di atas belum ada ditemukan dosis terbaik pemberian pupuk Grow Quick LB untuk tanaman anggrek Dendrobium. Berdasarkan latar belakang diatas penulis tertarik untuk melakukan penelitian tentang aklimatisasi tanaman anggrek Dendrobium dengan berbagai media tumbuh dan pemberian pupuk Grow Quick LB.

\section{METODOLOGI PENELITIAN}

Penelitian dilaksanakan dari bulan Mei hingga Juni 2016 di lahan F. MIPA Kampus II
Universitas Muhammadiyah Riau. Alat dan bahan yang digunakan yaitu pot tanah liat dengan ukuran diameter $15 \mathrm{~cm}$ dan tinggi $15 \mathrm{~cm}$, ember, gelas ukur $10 \mathrm{ml}$, pinset, handspayer, penggaris dan alat-alat tulis. Bahan yang digunakan adalah bibit anggrek Dendrobium siap tanam dalam botol kultur yang berumur 10 bulan yang diperoleh dari Ali Orchid Malang, pupuk daun Grow Quick LB, pakis, arang kayu, sabut kelapa, air, pupuk NPK Mutiara 16:16:16 dan fungisida Dithane M45 80WP.

Penelitian dilakukan secara eksperimen dengan menggunakan Rancangan Acak Lengkap (RAL) pola faktorial yang terdiri dari 2 faktor: Faktor 1 adalah jenis media yang terdiri dari 2 taraf yaitu:

$$
\begin{aligned}
& \text { M1= Arang }+ \text { Pakis } \\
& \text { M2= Arang }+ \text { Sabut Kelapa }
\end{aligned}
$$

Faktor 2 adalah pupuk Grow Quick LB yang terdiri dari 4 taraf yaitu: $\mathrm{G} 0=0 \mathrm{ml} / \mathrm{L}$

$$
\begin{aligned}
& \mathrm{G} 1=1 \mathrm{ml} / \mathrm{L} \\
& \mathrm{G}_{2}=2 \mathrm{ml} / \mathrm{L} \\
& \mathrm{G}_{3}=3 \mathrm{ml} / \mathrm{L}
\end{aligned}
$$

Dua faktor diatas menghasilkan kombinasi perlakuan sebanyak 8 kombinasi dengan 3 ulangan menjadi 24 satuan percobaan. Parameter yang diamati diantaranya tinggi tanaman, panjang daun, lebar daun dan jumlah daun. Data yang diperoleh dianalisis secara statistik menggunakan sidik ragam ANOVA dan bila data yang didapatkan berbeda nyata maka uji lanjutan dengan menggunakan Duncan's Multiple Range Test ( DMRT ) pada taraf 5\%.

\section{HASIL DAN PEMBAHASAN Hasil}

Pengamatan terhadap tanaman anggrek Dendrobium sp. dengan berbagai media tumbuh dan pemberian pupuk Grow Quick LB meliputi pengamatan tinggi tanaman, panjang daun, lebar daun, dan jumlah daun setelah tanaman anggrek diberi perlakuan selama 4 minggu. Data hasil penelitian tinggi tanaman, panjang daun, lebar daun, dan jumlah daun disajikan pada Tabel 3.1. 
Tabel 3.1. Rata-rata tinggi tanaman, panjang daun, lebar daun, dan jumlah daun anggrek Dendrobium sp. dengan berbagai media tanam dan dosis pupuk Grow Quick LB diberi perlakuan selama 4 minggu.

\begin{tabular}{|c|c|c|c|c|c|}
\hline \multirow{2}{*}{ Perlakuan } & \multirow{2}{*}{ Ulangan } & \multicolumn{4}{|c|}{ Parameter } \\
\cline { 3 - 6 } & & $\begin{array}{c}\text { Tinggi } \\
\text { tanaman }(\mathrm{cm})\end{array}$ & $\begin{array}{c}\text { Panjang daun } \\
(\mathrm{cm})\end{array}$ & $\begin{array}{c}\text { Lebar daun } \\
(\mathrm{cm})\end{array}$ & $\begin{array}{c}\text { Jumlah daun } \\
\text { (helai) }\end{array}$ \\
\hline M1G0 & 3 & 4 & 3,26 & 0,4 & 2 \\
\hline M1G1 & 3 & 4,53 & 3,23 & 0,5 & 1,6 \\
\hline M1G2 & 3 & 4,5 & 3,5 & 0,43 & 2,6 \\
\hline M1G3 & 3 & 4,76 & 3,7 & 0,5 & 2,6 \\
\hline M2G0 & 3 & 6,46 & 4,83 & 0,46 & 4 \\
\hline M2G1 & 3 & 6,56 & 4,83 & 0,73 & 1,6 \\
\hline M2G2 & 3 & 7,23 & 5,63 & 0,6 & 0,5 \\
\hline M2G3 & 3 & 6,56 & 5,1 & & \\
\hline
\end{tabular}

(Media) M1 = Arang+Pakis M2 = Arang+Sabut Kelapa

(Pupuk Grow Quick LB) G0 = 0ml/L G1 $=1 \mathrm{ml} / \mathrm{L} \mathrm{G} 2=2 \mathrm{ml} / \mathrm{L} \mathrm{G} 3=3 \mathrm{ml} / \mathrm{L}$

Tabel 3.1 menunjukkan tinggi tanaman tertinggi terdapat pada perlakuan $\mathrm{M} 2 \mathrm{G} 2$ yaitu $7,23 \mathrm{~cm}$, panjang daun terpanjang terdapat pada M2G2 yaitu 5,63 cm, lebar daun terlebar terdapat pada perlakuan $\mathrm{M} 2 \mathrm{G} 1$ yaitu $0,73 \mathrm{~cm}$, dan jumlah daun terbanyak terdapat pada perlakuan M2G1 yaitu 4 helai.

\section{Pembahasan}

\section{Tinggi tanaman}

Tinggi tanaman anggrek Dendrobium sp. dengan berbagai media tanam dan pemberian pupuk Grow Quick LB setelah diuji lanjut secara statistik dapat dilihat pada Tabel 3.2 berikut.

Tabel 3.2. Tinggi tanaman (cm) anggrek Dendrobium sp. dengan berbagai media tanam dan pemberian pupuk Grow Quick LB

\begin{tabular}{|c|c|c|c|c|c|}
\hline \multirow{3}{*}{ Media Tanam } & \multicolumn{4}{|c|}{ Pemberian Pupuk Grow } & \multirow{3}{*}{$\begin{array}{c}\text { Pengaruh } \\
\text { Utama } \\
\text { Media }\end{array}$} \\
\hline & $0 \mathrm{ml} / \mathrm{L}$ & $1 \mathrm{ml} / \mathrm{L}$ & $2 / \mathrm{I}$ & $3 \mathrm{ml} / \mathrm{L}$ & \\
\hline & (G0) & (G1) & (G2) & (G3) & \\
\hline Arang + Pakis (M1) & $4 a$ & $4,53 \mathrm{a}$ & $4,5 \mathrm{a}$ & $4,76 \mathrm{ab}$ & $4,45 \mathrm{a}$ \\
\hline Arang + Sabut Kelapa & $5,46 b$ & $6,56 b c$ & $7,23 \mathrm{c}$ & $6,56 b c$ & $6,70 \mathrm{~b}$ \\
\hline Pengaru & $5,32 \mathrm{a}$ & $5,55 \mathrm{a}$ & $5,86 \mathrm{a}$ & $5,66 \mathrm{a}$ & \\
\hline
\end{tabular}

Keterangan: Angka-angka yang berada pada kolom dan baris yang sama yang diikuti oleh huruf yang sama tidak berbeda nyata pada uji lanjut Duncan's Multiple Range Test (DMRT) pada taraf $5 \%$

Hasil pengamatan tinggi tanaman setelah dianalisis secara statistik (Tabel 3.2) menunjukkan bahwa interaksi perlakuan M2G2 menghasilkan tinggi tanaman tertinggi yaitu $7,23 \mathrm{~cm}$ dan berbeda nyata terhadap perlakuan M1G0, M1G1, M1G2, dan M1G3. Hal ini diduga karena kombinasi campuran media arang+sabut kelapa dengan pupuk Grow Quick LB 2ml/L telah memberikan nutrisi yang cukup untuk tinggi tanaman. Media arang+sabut kelapa merupakan kombinasi jenis media yang baik sebagai tempat berdirinya tanaman, walaupun arang memiliki sifat sukar mengikat air dan miskin zat hara namun dengan adanya campuran media sabut kelapa yang memiliki daya simpan air yang baik serta mengandung unsur hara yang diperlukan oleh tanaman maka kebutuhan akan air dan unsur hara tercukupi. Iswanto (2005), menyatakan media arang dibandingkan dengan media sabut kelapa, kemampuan mengikat airnya masih kalah dan miskin unsur hara sedangkan media sabut kelapa mempunyai daya simpan air yang sangat baik serta mengandung unsur hara yang diperlukan oleh tanaman. Febrizawati et al. (2014) menyatakan media tumbuh yang digunakan bukan berfungsi sebagai sumber unsur hara yang dibutuhkan anggrek.

Dilihat dari faktor pupuk, pemberian dosis $2 \mathrm{ml} / \mathrm{L}$ menghasilkan tinggi tanaman yang tertinggi yaitu $5,86 \mathrm{~cm}$ dan secara statistik tidak berbeda nyata dibandingkan dengan dosis lainnya. Pemberian pupuk Grow Quick LB dosis

$2 \mathrm{ml} / \mathrm{L}$ dapat diserap secara optimal dan telah memberikan nutrisi yang cukup untuk tinggi tanaman. Pemberian pupuk dengan dosis yang lebih rendah (G2) akan memperlihatkan hasil yang baik dibandingkan dengan pemberian 
pupuk dengan dosis tinggi (G3). Indarto (2015), menyatakan komposisi pupuk yang

melebihi dosis biasanya akan membakar anggrek dikemudian hari, karena itu sebaiknya dosis diturunkan. Sedangkan dilihat dari faktor jenis media, media M2 (arang+sabut kelapa) menghasilkan tinggi tanaman tertinggi yaitu 6,70 $\mathrm{cm}$ dan berbeda nyata dibandingkan media M1 (arang+pakis). Hal ini diduga karena media sabut kelapa memiliki tekstur yang halus dibandingkan media pakis sehingga pergerakan akar dalam menembus media lebih efektif pada media sabut kelapa. Gunawan (2001), menyatakan untuk seedling yang baru keluar dari botol, media tumbuh sebaiknya yang lebih halus.

\section{Panjang Daun}

Panjang daun anggrek Dendrobium sp. dengan berbagai media tanam dan pemberian pupuk Grow Quick LB setelah diuji lanjut secara statistik dapat dilihat pada Tabel 3.3 berikut.

Tabel 3.3. Panjang daun (cm) anggrek Dendrobium sp. dengan berbagai media tanam dan pemberian pupuk Grow Quick LB

\begin{tabular}{|c|c|c|c|c|c|}
\hline \multirow{2}{*}{ Perlakuan } & \multicolumn{3}{|c|}{ Pemberian Pupuk Grow Quick LB } & \multirow{2}{*}{$\begin{array}{c}\text { Pengaruh } \\
\text { Utama Media }\end{array}$} \\
\cline { 2 - 5 } & $0 \mathrm{ml} / \mathrm{L}(\mathrm{G} 0)$ & $1 \mathrm{ml} / \mathrm{L}(\mathrm{G} 1)$ & $2 \mathrm{ml} / \mathrm{L}(\mathrm{G} 2)$ & $3 \mathrm{ml} / \mathrm{L}(\mathrm{G} 3)$ & $3,46 \mathrm{a}$ \\
\hline Arang + Pakis (M1) & $3,26 \mathrm{a}$ & $3,23 \mathrm{a}$ & $3,5 \mathrm{ab}$ & $3,7 \mathrm{abc}$ & $5,1 \mathrm{~b}$ \\
\hline Arang + Sabut Kelapa (M2) & $4,83 \mathrm{bcd}$ & $4,83 \mathrm{bcd}$ & $5,63 \mathrm{~d}$ & $5,1 \mathrm{~cd}$ & \\
\hline Pengaruh Utama Pupuk & $4,05 \mathrm{a}$ & $4,03 \mathrm{a}$ & $4,56 \mathrm{a}$ & $4,48 \mathrm{a}$ & \\
\hline
\end{tabular}

Keterangan: Angka-angka yang berada pada kolom dan baris yang sama yang diikuti oleh huruf yang sama tidak berbeda nyata menurut uji lanjut Duncan's Multiple Range Test (DMRT) pada taraf 5\%.

Hasil pengamatan terhadap panjang daun setelah dianalisis secara statistik (Tabel 3.3) menunjukkan bahwa interaksi M2G2 menghasilkan panjang daun terpanjang yaitu $5,63 \mathrm{~cm}$ dan berbeda nyata terhadap perlakuan M1G0, M1G1, M1G2, dan M1G3. Hal ini diduga karena kebutuhan akan nutrisi unsur nitrogen $(\mathrm{N})$ telah tercukupi dengan pemberian pupuk Grow Quick LB 2ml/L. Peranan unsur N adalah merupakan salah unsur utama pendorong pertumbuhan. Nitrogen merupakan unsur esensial dalam sintesis protein, dan beberapa substansi penting lainnya yang berguna dalam pembentukan sel-sel baru dalam pertumbuhan. Menurut Julhendri et al. (2013) pupuk Grow Quick LB mengandung unsur $45 \%$ N, $15 \%$ P, $15 \%$ K. Selanjutnya Sutedjo (2010) menyatakan fungsi $\mathrm{N}$ untuk meningkatkan kadar protein dalam tubuh tanaman dan meningkatkan pertumbuhan daun. Lakitan (2015), menerangkan dalam jaringan tumbuhan, nitrogen merupakan komponen penyusun dari banyak senyawa esensial bagi tumbuhan seperti protein dan enzim. Tingginya kandungan $\mathrm{N}$ menyebabkan pembentukan protoplasma meningkat, ukuran sel bertambah besar, sehingga ukuran panjang daun pun akan meningkat.
Dilihat dari faktor pupuk, pemberian dosis $2 \mathrm{ml} / \mathrm{L}$ menghasilkan panjang daun terpanjang yaitu $4,56 \mathrm{~cm}$ dan secara statistik tidak berbeda nyata terhadap dosis lainnya. Selain unsur N, pupuk Grow Quick LB juga mengandung fosfor dan kalium. Menurut Iswanto (2005), unsur kalium $(\mathrm{K})$ mempunyai peranan penting sebagai katalisator, terutama dalam penguraian protein menjadi asam amino serta penyusunan dan penguraian karbohidrat. Lakitan (2015), menyatakan unsur fosfor $(\mathrm{P})$ merupakan bagian esensial yang berperan dalam reaksi fotosintesis dan respirasi. Kekurangan unsur NPK maka panjang daun juga akan menurun dan bila dosis NPK berlebihan maka panjang daun juga akan menurun sebagaimana yang terlihat pada hasil penelitian yang telah dilakukan pada Tabel 4.3. Sedangkan dari faktor media, media arang+sabut kelapa menghasilkan panjang daun terpanjang yaitu $5,1 \mathrm{~cm}$ dan berbeda nyata terhadap media arang+ + pakis.

\section{Lebar Daun}

Lebar daun anggrek Dendrobium sp. dengan berbagai media tanam dan pemberian pupuk Grow Quick LB setelah diuji lanjut secara statistik dapat dilihat pada Tabel 3.4 berikut. 
Tabel 3.4. Lebar daun (cm) anggrek Dendrobium sp. dengan berbagai media tanam dan pemberian pupuk Grow Quick LB

\begin{tabular}{|c|c|c|c|c|c|}
\hline \multirow{2}{*}{ Perlakuan } & \multicolumn{4}{|c|}{ Pemberian Pupuk Grow Quick LB } & \multirow{2}{*}{$\begin{array}{c}\text { Pengaruh } \\
\text { Utama Media }\end{array}$} \\
\cline { 2 - 5 } & $0 \mathrm{ml} / \mathrm{L}(\mathrm{G} 0)$ & $1 \mathrm{ml} / \mathrm{L}(\mathrm{G} 1)$ & $2 \mathrm{ml} / \mathrm{L}(\mathrm{G} 2)$ & $3 \mathrm{ml} / \mathrm{L}(\mathrm{G} 3)$ & $0,45 \mathrm{a}$ \\
\hline Arang + Pakis (M1) & $0,4 \mathrm{a}$ & $0,5 \mathrm{a}$ & $0,43 \mathrm{a}$ & $0,5 \mathrm{a}$ & $0,57 \mathrm{a}$ \\
\hline Arang + Sabut Kelapa (M2) & $0,46 \mathrm{a}$ & $0,73 \mathrm{a}$ & $0,6 \mathrm{a}$ & $0,5 \mathrm{a}$ & \\
\hline Pengaruh Utama Pupuk & $0,43 \mathrm{a}$ & $0,61 \mathrm{a}$ & $0,51 \mathrm{a}$ & $0,5 \mathrm{a}$ & \\
\hline
\end{tabular}

Keterangan: Angka-angka yang berada pada kolom dan baris yang sama yang diikuti oleh huruf yang sama tidak berbeda nyata menurut uji lanjut Duncan's Multiple Range Test (DMRT) pada taraf 5\%

Hasil pengamatan lebar daun setelah dianalisis secara statistik (Tabel 3.4) menunjukkan bahwa interaksi M2G1 menghasilkan lebar daun terlebar yaitu 0,73

$\mathrm{cm}$, namun secara statistik tidak ada perbedaan secara nyata antar perlakuan lainnya. Begitu pula dilihat dari faktor pupuk, pemberian dosis $1 \mathrm{ml} / \mathrm{L}$ menghasilkan lebar daun terlebar yaitu $0,61 \mathrm{~cm}$ dan secara statistik tidak berbeda nyata terhadap dosis lainnya, artinya pupuk dan jenis media tidak memberikan pengaruh terhadap lebar daun. Hal ini diduga karena berdasarkan morfologi bentuk daun, anggrek Dendrobium sp. memiliki bentuk daun lanset yaitu lonjong memanjang sehingga pertambahan ukuran lebar daun tidak secepat pertambahan panjang daun.
Tjitrosoepomo (2007), menyatakan bentuk daun bangun lanset yaitu daun yang ukuran panjangnya 3-5 kali dari ukuran lebar daun.

Sedangkan dari faktor media, jenis media arang+sabut kelapa menghasilkan daun terlebar yaitu $0,57 \mathrm{~cm}$ dan tidakberbeda nyata terhadap media arang+pakis. Media sabut kelapa memiliki tekstur lebih halus dibanding media pakis sehingga tanaman yang ditumbuhkan pada media arang+sabut kelapa menghasilkan lebar daun yang lebih lebar.

\section{Jumlah Daun}

Jumlah daun anggrek Dendrobium sp. dengan berbagai media tanam dan pemberian pupuk Grow Quick LB setelah diuji lanjut secara statistik dapat dilihat pada Tabel 3.5 berikut.

Tabel 3.5. Jumlah Daun anggrek Dendrobium sp. dengan berbagai media tanam dan pemberian pupuk Grow Quick LB

\begin{tabular}{|c|c|c|c|c|c|}
\hline \multirow{2}{*}{ Perlakuan } & \multicolumn{3}{|c|}{ Pemberian Pupuk Grow Quick } & \multirow{2}{*}{$\begin{array}{c}\text { Pengaruh } \\
\text { Utama Media }\end{array}$} \\
\cline { 2 - 5 } & $0 \mathrm{ml} / \mathrm{L}(\mathrm{G} 0)$ & $1 \mathrm{ml} / \mathrm{L}(\mathrm{G} 1)$ & $2 \mathrm{ml} / \mathrm{L}(\mathrm{G} 2)$ & $3 \mathrm{ml} / \mathrm{L}(\mathrm{G} 3)$ & $2,3 \mathrm{a}$ \\
\hline Arang + Pakis (M1) & $2 \mathrm{a}$ & $1,66 \mathrm{a}$ & $3 \mathrm{a}$ & $2,66 \mathrm{a}$ & $2,5 \mathrm{a}$ \\
\hline Arang + Sabut Kelapa (M2) & $2,66 \mathrm{a}$ & $4 \mathrm{a}$ & $2 \mathrm{a}$ & $1,66 \mathrm{a}$ & \\
\hline Pengaruh Utama Pupuk & $2,3 \mathrm{a}$ & $2,8 \mathrm{a}$ & $2,5 \mathrm{a}$ & $2,1 \mathrm{a}$ & \\
\hline
\end{tabular}

Keterangan: Angka-angka yang berada pada kolom dan baris yang sama yang diikuti oleh huruf yang sama tidak berbeda nyata menurut uji lanjut Duncan's Multiple Range Test (DMRT) pada taraf 5\%

Hasil pengamatan jumlah daun setelah dianalisis secara statistik (Tabel 3.5) menunjukkan bahwa interaksi M2G1 menghasilkan jumlah daun terbanyak yaitu 4 helai dan tidak menunjukkan pengaruh yang signifikan terhadap perlakuan lainnya. Hal ini diduga karena adanya faktor lingkungan seperti hama dan penyakit. Tanaman mempunyai potensi terserang hama penyakit, pada penelitian ini ditemukan adanya tanaman yang mengalami pembusukan daun sehingga daun berjatuhan (Lampiran 4). Indarto (2015), menyatakan salah satu hama penyakit yang menyerang Dendrobium sp. adalah busuk hitam. Infeksi tampak dengan adanya noda-noda hitam yang menjalar dari tengah tanaman hingga ke daun. Dalam waktu yang relatif singkat daun mulai berjatuhan. Bagian pangkal pucuk daun terlihat basah dan bila ditarik mudah terlepas. Penyebaran penyakit ini sangat cepat bila lingkungan lembap.

Dilihat dari faktor pupuk, pemberian dosis $1 \mathrm{ml} / \mathrm{L}$ menghasilkan jumlah daun tebanyak yaitu 
2,8 helai dan secara statistik tidak berbeda nyata terhadap dosis lainnya. Sedangkan dari faktor media, jenis media arang+sabut kelapa menghasilkan jumlah daun terbanyak yaitu 2,5 helai dan secara statistik tidak berbeda nyata terhadap media arang+pakis.

\section{KESIMPULAN}

Berdasarkan hasil penelitian yang telah dilakukan, maka dapat disimpulkan sebagai berikut.

1. Pemberian dosis pupuk Grow Quick LB $1 \mathrm{ml} / \mathrm{L}$ menghasilkan daun terlebar 0,61 $\mathrm{cm}$, dan jumlah daun terbanyak yaitu 2,8 helai daun. Sedangkan dosis $2 \mathrm{ml} / \mathrm{L}$ menghasilkan tinggi tanaman tertinggi $5,86 \mathrm{~cm}$, dan panjang daun terpanjang $4,56 \mathrm{~cm}$.

2. Kombinasi jenis media tanam arang+sabut kelapa menunjukkan efek yang lebih baik dibandingkan media arang+pakis terhadap seluruh parameter tanaman yaitu, 6,70 untuk parameter tinggi tanaman, 5,1 untuk parameter panjang daun, 0,57 untuk parameter lebar daun, dan 2,5 untuk parameter jumlah daun.

3. nteraksi media tanam dan pupuk Grow Quick LB terhadap tanaman anggrek Dendrobium sp. menunjukkan nilai yang berbeda nyata antar perlakuan pada parameter tinggi tanaman dan parameter panjang daun, sedangkan untuk parameter lebar daun dan parameter jumlah daun interaksi media dan pupuk Grow Quick LB terhadap tanaman anggrek Dendrobium sp. menunjukkan nilai tidak berbeda nyata antar kelompok perlakuan.

\section{DAFTAR PUSTAKA}

Bakrie, A. 2008. Pertumbuhan Vegetatif Tanaman Anggrek Dendrobium

(Dendrobium sp.) pada Aplikasi Zeolit Sebagai Campuran Media tanam dan Pupuk Pelengkap Cair. Jurnal Zeolit Indonesia. Vol.7 No. 1Hal. 53-60.
Febrizawati, Murniati, Sri Yoseva. Pengaruh Komposisi Media Tanam dengan Konsentrasi Pupuk Cair Terhadap Pertumbuhan Tanaman Anggrek Dendrobium (Dendrobium sp). Jurnal Faperta. Vol. 1 No. 2 Hal. 1-11.

Gunawan, L. 2001. Budidaya Anggrek. Jakarta. Penebar Swadaya.

Indarto, N. 2015. Pesona Anggrek: Petunjuk Praktis Budidaya \& Bisnis Anggrek. Yogyakarta. Cahaya Atma.

Iswanto, H. 2005. Petunjuk Perawatan Anggrek. Jakarta. Agromedia Pustaka. Junaedhie, K. 2014. Membuat Anggrek Pasti Berbunga. Jakarta. AgromediaPustaka.

Julhendri, Hercules G., Fathurrahman. 2013. Aklimatisasi Tanaman Anthurium (Anthurium sp) dengan berbagai macam media tumbuh dan Pupuk Daun Grow Quick. Jurnal Dinamika Pertanian.Vol. 28 No. 2 Hal 103-112.

Lakitan, B. 2015. Dasar-Dasar Fisiologi Tumbuhan. Jakarta. Rajawali Pers.

Purnami, N.G., Hestin, Y., AA. Made, A.2014.Pengaruh Jenis dan Frekuensi Penyemprotan Leri Terhadap Pertumbuhan Bibit Anggrek Phalaeonopsis sp. Pasca Aklimatisasi. Jurnal Argoteknologi Tropika.Vol.3 No. 1 Hal.22-31.

Surtinah, dan E. Mutryarny. 2013. Frekuensi Pemberian Grow Quick LB Terhadap Pertumbuhan Bibit Anggrek Dendrobium Pada Stadia Komunitas Pot. Jurnal Ilmiah Pertanian. Vol. 10 No. 2 Hal 31-40.

Sutedjo, M. 2010. Pupuk dan Cara Pemupukan. Jakarta. Rineka Cipta.

Stennis, C.G.G.J.. 2002. Flora: Untuk Sekolah di Indonesia. Jakarta. PT Pradnya Paramita.

Sutrian, Y. 2011. Pengantar Anatomi TumbuhTumbuhan Tentang Sel dan Jaringan. Jakarta . Rineka Cipta.

Tjitrosoepomo, G.2007. Morfologi Tumbuhan. Yogyakarta. Gadjah Mada University Press.

Wardani, S., Setiado,H., Syarifuddin, I .2009. Pengaruh Media Tanam dan Pupuk Daun terhadap Aklimatisasi Anggrek Dendrobium (Dendrobium sp). Jurnal 
Argo Ekoteknologi Pertanian USU.Vol.1 No.1 Hal.11-16.

Widiastoety, D., Santi, A., Solvia, N. 2012. Pengaruh Myoinositol dan Arang Aktif terhadap Pertumbuhan Planlet Anggrek
Dendrobium dalam Kultur In Vitro. Jurnal Hortikultura. Vol. 22 No. 3 Hal. 205-209. Yuwono, T. 2008. Bioteknologi Pertanian. Yogyakarta. Gadjah Mada University Press.

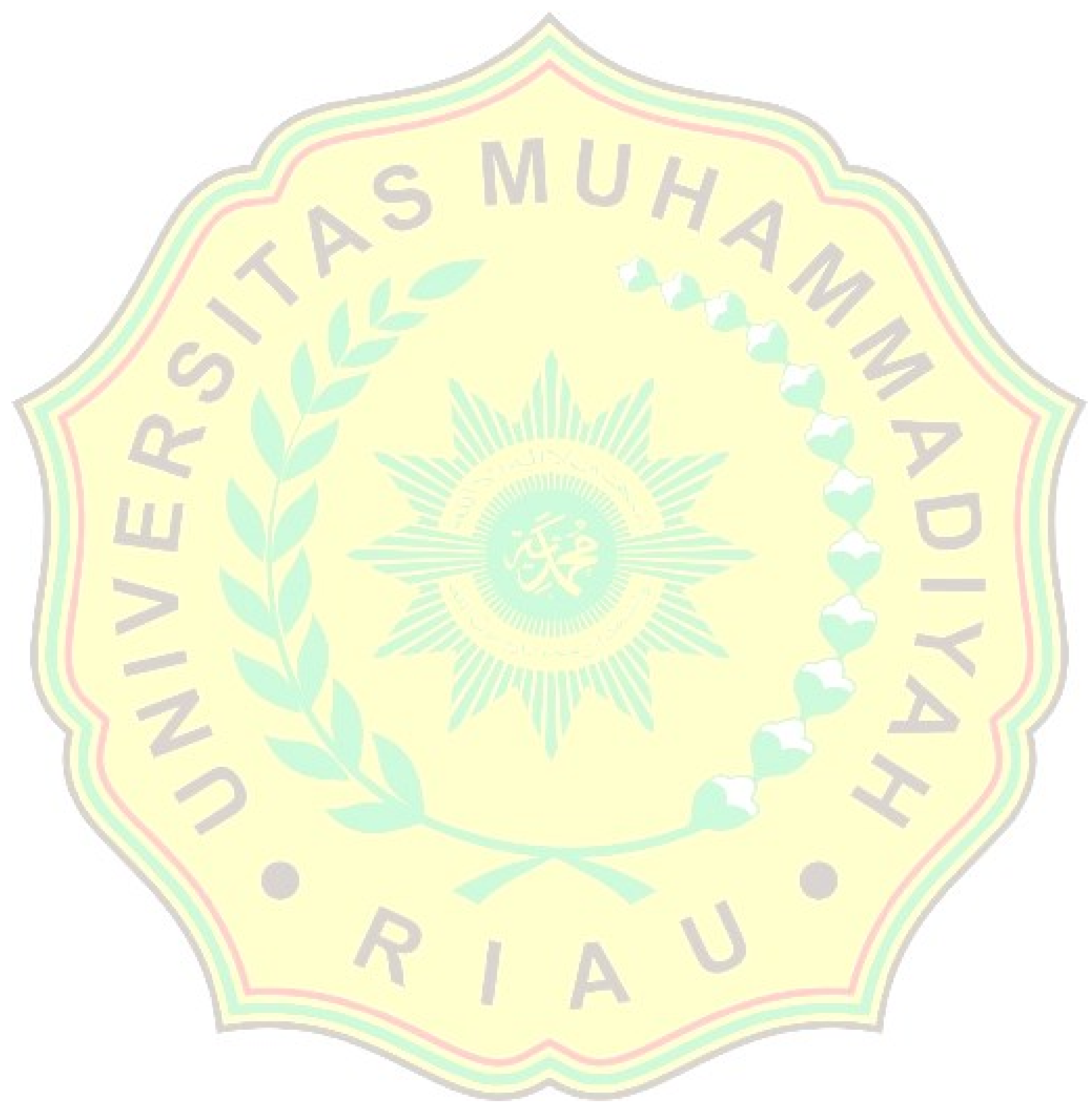

